\title{
Civilitika - A civil társadalom kialakulása Nyugat- és Közép-Európában, illetve Magyarországon
}

\section{Civil Studies: Evolution of the Concept of Civil Society; Civil Society in Western and Central Europe and in Hungary}

\begin{abstract}
o.
Összefoglalás

A tanulmány a civilitikával mint új társadalomtudományi elemzési iránnyal, a civil társadalom elméletével és gyakorlatával foglalkozik. Az írás a civil társadalom történeti kialakulásának, illetve az alapvetô fogalmi-elméleti kereteknek a rövid áttekintésére vállalkozik, emellett azt vizsgálja, hogy Nyugat- és Közép-Európában, illetve Magyarországon milyen konkrét formában és változatban jött létre, jön létre a civil társadalom. A tanulmány célja bemutatni, hogy a közép-európai régióban és hazánkban a civil társadalom fokozatos újjászületésének vagyunk a szemtanúi, ám ez a folyamat még rengeteg ellentmondással terhelt, a demokratikus civil szervezódéseket többféle - gazdasági, külpolitikai, ideológiai - kihívás éri, ezért a kedvezó jelek ellenére a civil társadalom stabilizációjáról és konszolidációjáról csak részben beszélhetünk.
\end{abstract}

Kulcsszavak: civil társadalom, civil szervezetek, demokrácia, citoyen

Dr. Fricz Tamás PhD, egyetemi docens, tudományos kutató, Rendszerváltás Történetét Kutató Intézet (fricztamas@gmail.com). 
Polgári Szemle · 15. évfolyam 1-3. szám

\section{Summary}

The following study is concerned with civil studies, a new branch of social sciences analyses the theory and practice of civil society. In the first half of the study, the author presents the historical emergence of civil society and briefly reviews the evolution of its concept, while in the second part the tangible form is analysed in which civil society has been evolving in Western and Central Europe, as well as in Hungary. The purpose is to present that in the Central European region and in Hungary the gradual rebirth of civil society is witnessed, however, this process is still strained by several controversies, and as the democratic civil organisations are facing multiple - economic, foreign affairs and ideological - challenges, in spite of the favourable signs, the stabilization and consolidation of civil society has remained partial and incomplete.

Keywords: civil society, NGO, democracy, citoyen

\section{BEVEZETő}

A civilitika mint társadalomtudományi elemzési irány a civil társadalom elméletével és gyakorlatával foglalkozik. Témái közé tartozik a közéletben részt vevô állampolgár és annak szervezôdései, a civil intézmények és mozgalmak, a civil szervezetek viszonya az állami intézményekhez, a civil etika, a civil társadalom demokratikus rendszerben betöltött szerepe, a civil közpolitikai tevékenység, a határokon átívelô, nemzeti és nemzetközi civil tevékenység, és még lehetne sorolni. Fontos kiemelni, hogy a civilitika egyszerre empirikus és analitikus: egyfelól feltárja a konkrét civil és állampolgári szervezôdések világát, tényekkel, adatokkal és dokumentumokkal, az egyes országok vonatkozásában és nemzetközi összehasonlításban is, bemutatja a civil társadalom múködését meghatározó vagy befolyásoló jogi-alkotmányos környezetet, a politikai berendezkedés, a gazdasági-piaci szféra és a civil szervezetek egymásra gyakorolt hatását, a civil tevékenység finanszírozásának kérdéseit, az állam és a civil társadalom közötti erôviszonyok alakulását, a civil szervezetek politikabefolyásoló tevékenységét. Másfelól, az empirikus, szociológiai jellegú adat- és tényfeltáráson túl a civil tevékenység fogalmi és elméleti kereteit is kidolgozza, s a történeti-politikai-társadalmi változásoknak megfelelően azokat állandóan újraértelmezi és finomhangolja.

\section{A CIVIL TÁRSADALOM FOGALMA}

A polgár szabadságát az egyéni és állampolgári jogok garantálják. A polgár - az állampolgár - azonban nem pusztán egyén, individuum, hanem egy nemzet és egy társadalom tagja is. Különféle közösségekben vesz részt, melyek együttesen alkotják a civil - vagy polgári - társadalmat. A polgár tehát nem magányos Robinson, aki pusztán az 
Fricz Tamás: Civilitika - A civil társadalom kialakulása Nyugat-és Közép-Európában...

egyéni jogai és kötelességei alapján cselekszik, hanem egyben közösségi lény is, s utóbbi esetében a civil társadalom része.

A civil (polgári) társadalom a modern államtól független, közélet-orientált, szabadon cselekvó polgárok, egyének és csoportok világa. A tágabb értelemben vett társadalom két részre oszlik: magántársadalomra, amely a privát cselekvések terepe, ideértve az egyén mindennapi életét, a családot, a kulturális és szabadidôs tevékenységeket stb.; és civil társadalomra, amely a polgárok közéleti tevékenységeit foglalja magában, ideértendố a döntésbefolyásolás, az egyesületek, alapítványok, szakszervezetek, mozgalmak, sajtó, állampolgári kezdeményezések stb. terepe. A társadalomnak ez az a szférája, amely az állam feletti kontrollt gyakorolja.

A civil társadalom nem önmagában létezik: léte az államhoz való viszonyban értelmezhetô. Civil társadalom és állam szimbiózisban áll egymással: nincs állam - mármint demokratikus állam - független civil társadalom nélkül, s nincs független civil társadalom állam nélkül.

\section{A CIVIL TÁRSADALOM TÖRTÉNETI „KIALAKULÁSA”}

A civil társadalom és az állam fogalma egészen a 18. századig nem vált külön egymástól; ekkortól a polgári filozófiában különválasztják a két fogalmat. A kapitalista korszak előtti középkorban állam és társadalom sajátos „egységben” jelentkezett; a rendi, feudális viszonyok között az állam hatalmi hierarchiái megjelentek a társadalmi viszonyokban is. A társadalom, a gazdaság, a kultúra felolvadt az államban, az állam volt a meghatározó szféra, a társadalom pedig az alárendelt. A 18. században viszont, szoros összefüggésben a kapitalizmus és a polgárság kialakulásával, angol, skót, amerikai és francia szerzók kezdték el emlegetni az államtól független civil társadalmat. A skót szerzók, mint például Ferguson vagy Adam Smith, követelték, hogy az államról le kell választani a civil társadalmat, és külön entitásként kell kezelni, fóleg gazdasági okok miatt. Számukra a kapitalizmus, a vállalkozás függetlensége, önállósága volt a meghatározó szempont, hiszen abból indultak ki, hogy a vállalkozó csak akkor képes haszon termelésére, ha független az államtól, az állam nem szól bele a ténykedésébe, s nem vonja el tôle a munkája profitját. Az angol Locke-nál ezzel szemben a kormányzás és a civil (polgári) társadalom viszonya jelent meg, az amerikai Paine a despotizmussal, az elnyomással szemben fogalmazta meg a civil, polgári társadalom jelentóségét, míg a francia Montesquieu a hatalommegosztás fontosságáról beszélt.

A civil vagy polgári társadalom leválása az államról a kapitalizáció megjelenésével és a polgárság kialakulásával áll összefüggésben. A vállalkozó polgár (bourgeois) elsôdleges érdeke volt, hogy önálló cselekvési terepe legyen, amelybe nem szólhat bele az állam. Ez a liberalizmus alapgondolata is, s bár az önállósodás szándéka gazdasági alapú, eleinte ennek jogi-politikai vonatkozásai domináltak, döntôen azért, mert a civil vagy polgári társadalom jogi függetlensége jelenthette a garanciát a polgárság, a burzsoázia gazdasági szabadságához.

A 19. századra, a polgári forradalmak, az amerikai függetlenségi háború, valamint az angliai fokozatos változások következtében a civil vagy polgári társadalom létjo- 
gosultságot nyert, jogi értelemben elnyerte az államtól való függetlenségét, fokozatosan elfogadottá váltak az emberi és állampolgári jogok, legalábbis a nyugat-európai és észak-amerikai régióban. Az állam és a társadalom jogi-államjogi-alkotmányos különválasztása után a civil társadalom gazdasági oldala is egyre inkább a politikai gondolkodók figyelmének fókuszába került, hiszen a jogi-alkotmányjogi autonómia után fontossá vált a piaci, vállalkozói, tulajdonosi autonómia, annak az igénye, hogy az állam immáron gazdaságilag se tudjon beavatkozni a polgárság, a burzsoázia tevékenységébe.

Ezekre a változásokra két német filozófus, Hegel és Marx is felhívta a figyelmet. Mindketten polgári társadalomról (bürgerliche Gesellschaft) beszéltek, mégis eltérô módon. Marxnál a civil társadalom megegyezik a polgári (burzsoá) társadalommal, azaz nála ez a szféra túlzottan a gazdasági emberre, a vállalkozóra koncentrálódik. Marx nem látta meg a civil társadalom politikai jelentóségét, s mivel a kapitalizmust vehemensen elutasította, ezért nem láthatta meg a civil társadalomban rejló pozitív, demokratikus alapértékeket sem. Hegelnél más a kiindulópont: a polgári társadalom több a gazdaságnál, abba beletartoznak a társadalom legváltozatosabb közintézményei, a kulturális szféra, a bíróság, az oktatás, a rendőrség stb. Hegel szerint a polgári (civil) társadalom a család és az állam között helyezkedik el, s morális funkciója is van (Hegel, 1971). Kérdés az, honnan a morális funkció? Hegel válasza az, hogy a polgári társadalom túlnő az egyénen, benne megjelenik a közösség mint egység, így a polgári társadalom nem más, mint közvetítô közeg, amelyben az egyén képes felfogni, észlelni, megélni a közösséget, a társadalmat és a nemzetet, s ezáltal eljut az államig. Ez pedig felelôsséggel tölti el a közösségi, állami, nemzetállami ügyek iránt, s a közösségi, állami cselekvéssel szemben normák fogalmazódnak meg benne. A polgári társadalom tehát az egyéni önzés és az állam között képez hidat; ezt a gondolatot fejtették ki más és más megközelítésból olyan szerzôk is, mint Saint-Simon, Tocqueville, Durkheim, Tönnies, Parsons.

Marx persze jogosan feltételezte, hogy a polgári társadalom eredetileg valóban a kapitalizmus kifejlődésének a terepe, ahol a szabad tulajdonmozgás megvalósulhat. (A tulajdon kiszabadul az ókori és középkori államcentrikus társadalmak kötöttségei alól.) Tény, hogy a civil társadalom lényege a polgárság megléte és múködése, de nemcsak a burzsoá, tehát a gazdasági ember, a vállalkozó, hanem az állampolgár, a honpolgár (citoyen) terepe is, akiben immáron a közösségi felelősség is megjelenik. Mindez nem véletlen, hiszen a gazdasági ember, a tulajdonos vállalkozó „biztonsága” csak az állam korlátozásán és ellenôrzésén keresztül valósulhat meg, ehhez viszont már állampolgári mentalitás szükséges, mely több, mint a burzsoá önzés. Magyarul, a vállalkozás és a vállalkozó polgár szabadságának is feltétele a közösségben gondolkodó polgár megléte. Ebból kiindulva, a polgár két vonása jelenik meg: a burzsoá, a gazdasági polgár, a tulajdonos vállalkozó; illetve a citoyen, az állampolgár vagy honpolgár, a közösségi, morális lény. Hegelen itt már túllépve, kijelenthetjük, hogy a modern értelemben használt civil társadalom a citoyenek, az állampolgárok vagy honpolgárok világa, akik közösségben gondolkodnak, erkölcsi normákat követnek, s közvetlen kapcsolatban állnak az állammal, ellenôrzik annak tevékenységét. 
Fricz Tamás: Civilitika - A civil társadalom kialakulása Nyugat-és Közép-Európában...

Természetesen a burzsoá, a vállalkozó is lehet citoyen, sôt, ez a kívánatos, és fordítva, a citoyen is lehet egy személyben vállalkozó. Jelen korunkban bóven van példa arra, hogy a gazdasági emberek citoyenként is múködnek, vagy fordítva. Ám a modern kor legfőbb sajátossága mégis az, hogy a gazdasági szféra emberei különválnak a civil társadalomtól, és saját logikájuk szerint múködnek. Modern szóhasználat szerint a „piac”, a „befektetők” világa mára jócskán különvált a morális, közösségi felelôsséggel rendelkezô citoyen-, honpolgári világtól, önálló logika és döntési mechanizmus vezeti az elóbbi szférát. Sót, igazából arról beszélhetünk, hogy kialakult az állam, a civil társadalom és a piac (vagy gazdaság) hármassága, s legújabb kori jelenség, hogy a piaci szereplôk (pénzügyi alapok, bankok, nemzetközi pénzintézetek, befektetôk, globális pénzügyi csoportok stb.) nemhogy közösségi felelôsséggel rendelkeznének, ellenkezôleg, igyekeznek megszerezni a hatalmat mind az állam, mind a civil társadalom felett.

Ez már a 21. század kihívása, s éppen a piac túlterjeszkedése és globális uralomvágya miatt óriási a jelentôsége annak, hogy mennyire erôs a civil társadalom és az állam, illetve, hogy milyen hatékony és jól intézményesült a két szféra közötti viszony. Nagy bizonyossággal mondhatjuk, hogy e két szféra, illetve a közöttük kialakuló kapcsolatrendszer hatékonysága a garanciája a demokrácia és a szabadság fennmaradásának, de a kettô közül is különösen meghatározó a civil társadalom szervezettsége. Utóbbi azért állítható, mert ugyan az állam is a közösség, a nemzetközösségek jólétében érdekelt, és a közjó elérése a célja, mégis, az állami hatalmi monopóliumok megléte miatt még demokratikus viszonyok között is kerülhet olyan politikai kalandorok kezébe a kormányzás, akik az államot eltérítik a közösség iránti felelősségtôl, és az önkény, az autokrácia irányába mozdítják el a politikai rendszer és a közélet egészét.

Ezzel szemben a civil társadalom a „par excellence”, önmagában vett közösségiség, amely eleve nem rendelkezik olyan hatalmi jogosítványokkal, melyek eltéríthetnék az önkény, az autokrácia irányába. Elsôdleges funkciója éppen az, hogy az állam morális kontrollját adja, az államot korlátozza hatalma kiterjesztésében, illetve együttmúködjön vele a demokratikus játékszabályok betartása, a közjó megteremtése érdekében. A civil társadalom az önmagában vett demokrácia: a demokrácia csak a jól múködô civil társadalom által teremtôdhet, illetve, a demokrácia nem más, mint egy jól tagolt, erkölcsi és normatív alapokon álló civil társadalom megtestesülése az államban. Mindebból fakad a civil társadalom modern korban vett kiemelkedô jelentôsége, mely egyszerre a demokrácia garanciája, a demokratikus állam védelmezôje, illetve a piac globális uralmi terveinek korlátozója.

Érdemes ezek után figyelmünket a civil társadalom és az állam viszonyára koncentrálnunk. Kiindulópontként megfogalmazható, hogy a civil társadalom és az állam viszonya kölcsönös, nem lehet az egyiket a másik fölé helyezni. (Itt jegyzendó meg, hogy a szélsôséges, diktatórikus politikai irányzatok az államot emelik piedesztálra, míg az anarchisták és radikális liberálisok a civil társadalom szerepét túlozzák el.) Az állam nem mindig a megtestesült Rossz, mint ahogyan a civil társadalom sem a megtestesült Jó. Kétségtelen például, hogy nyolcvanas évek Lengyelországában a Jaruzelski-féle rendórállammal szemben állt a Szolidaritás által szervezett civil társadalom, s ekkor 
valóban a civil társadalom volt a „Jó”. De lehet ellenpéldát is találni: Indiában az állam, a politika már évtizedek óta demokratikus körülmények között múködik, miközben a „civil társadalom” a mai napig olyan középkori kasztrendszerben él, mely éppen a polgári függetlenség, egyenjogúság és szabadság esélyét nem adja meg; ebben az esetben tehát sokkal inkább az állam a „Jó”.

E példákkal arra utalok, hogy egy jó civil társadalom megléte még nem garancia arra, hogy jó állam is múködjék, s fordítva, a közjó és demokrácia iránt elkötelezett állam sem mindig tudja megoldani a társadalmakban felgyülemlett, múltból fennmaradt problémákat. Stabil és tartós demokrácia csak ott fejlődhet ki, ahol egy jól kiépített, tagolt, intézményesedett civil társadalomra épül fel egy demokratikusan múködô, erkölcsi normákat betartó állam. Az alap tehát a civil társadalom, amely azonban nem sokra jutna egy közjó iránt elkötelezett, demokratikus jogállam nélkül.

A civil társadalom jogi-alkotmányos függetlensége az államtól - mely nélkül nem is létezne - mára már megvalósult, a modern demokráciákban evidenciának számít. Létezik azonban egy újabb kihívás is, melyre Jürgen Habermas német filozófus hívta fel a figyelmet. Habermas szerint a modern társadalmak alrendszerekre esnek szét, amelyek között nincs kapcsolat, s e rendszerek gyarmatosítják az úgynevezett „életvilágot" (utóbbit felfoghatjuk úgy is, mint civil társadalom), behatolnak abba, uralják azt. E folyamat eredményeképpen viszont elveszik az „uralommentes kommunikáció” terepe. Habermas itt azt feszegeti, hogy nemcsak az állami politikai diktatúra a veszélyes a civil létre nézve, hanem az állam szinte észrevétlen „társadalmasodása” is, amellyel mintegy manipulálja a civil társadalmat, állami „logikát” visz a civil kommunikációba (Habermas, 1993).

Mindez arra figyelmeztet, hogy ugyan a modern demokráciákban a civil társadalom általában már nem szorul jogi védelemre - bár országonként előfordulhatnak ilyen problémák is -, viszont védeni kell a tartalmi függetlenségét, hogy autonómiáját és arculatát megórizhesse. Különösen a közép- és kelet-európai új demokráciákban megfigyelhetô jelenség, hogy amíg az államok, kormányok és pártok deklarálják a civil szervezeti lét függetlenségét és autonómiáját, közben a legkülönfélébb informális úton igyekeznek a civil szervezetekben és mozgalmakban „megjelenni”, „ott lenni”, s egyben meghatározni, hogy a civilek milyen célokat túzzenek ki, milyen eszközöket alkalmazzanak, mirôl folytassanak diskurzusokat a nyilvánosság elôtt stb. A befolyásolás formái különbözőek, a pénzügyi függóség kialakításától kezdve egészen a civilek politikába való csábításáig, ami azért veszélyes, mert az adott ország civil szférája könnyen válhat valóságosan függetlenből csak formálisan független, látszólag önálló, valójában azonban a politikai pártok és kormányok befolyása alatt álló, azok által eszközként irányított álcivil társadalommá. Ebben az esetben ugyanis, ha az állam informálisan megszünteti a civil szféra „uralommentes kommunikációját”, akkor a civil társadalom politizálódik, „államosodik”, megszúnik az az ellenőrző, morális és közösségorientált funkciója, ami a demokrácia elsődleges garanciája.

Mindezek fényében kell hangsúlyozni, hogy a civil társadalom függetlenségének nemcsak jogi-alkotmányos, hanem pénzügyi és tartalmi feltételei is vannak. Fontos, hogy a civil szervezeteket segítố állami pénzelosztás - ami nélkül nehezen múködik a 
Fricz Tamás: Civilitika - A civil társadalom kialakulása Nyugat-és Közép-Európában...

civil szféra - mechanizmusa semleges, transzparens és átlátható legyen. Másfelôl legalább olyan fontos, hogy a civil társadalom belsô közéletébe a pártok és a kormányok ne hatolhassanak bele, a civil társadalom nem válhat az állam visszhangjává, hanem a független és önálló diskurzus alakítsa a civil szféra céljait, témáit, konfliktusait és párbeszédeit az állammal.

\section{A givil társadalom Nyugaton, ILLETVE KözÉP- ÉS Kelet-EuRóPÁbaN}

Alapvetô kérdés - amire még nem tudhatjuk a választ -, hogy a közép- és kelet-európai régióban megvalósítható-e ugyanolyan civil társadalom, mint Nyugat-Európában, hiszen a történelmi fejlôdés a két régióban alapjaiban eltér egymástól. Nyugat-Európában a demokratizáció bottom-up (alulról felfelé) irányuló folyamat volt, amelynek lényege, hogy elôször a társadalom erôsödött meg, tagolódott, függetlenedett az államtól, majd már mint civil társadalom kényszerítette ki az állam demokratizálódását, a jogállam kialakulását. Ezzel szemben Közép- és fơleg Kelet-Európában top-down (felülrôl lefelé) irányuló folyamat zajlott le: a változások kívülrôl és felülrôl érkeztek, a Szovjetunió összeomlása után az egyes országok ellenzéki elitjei demokratizálták az államot, szabad választásokat tartottak, többpártrendszert vezettek be, új alkotmányt hoztak létre. S csak ezek után, az állam demokratizálása után került-kerül sor a civil társadalom, az állampolgári, citoyen politikai kultúra lassú és nehéz kialakulására.

Nagyon valószínú, hogy ezek a történelmi adottságok nem változnak meg egykönynyen, nevezzék bár a politikai rendszert diktatúrának avagy demokráciának. Ez különösen Kelet-Európára igaz; Közép-Európa esetében más a helyzet, itt egy „köztes” fejlődéssel van dolgunk, hiszen ebben az alrégióban a civil mozgalmaknak mindig sokkal több mozgásterük volt, mint keletebbre. A civil társadalom bizonyos kiépítettsége a második világháború elótti idôkig megfigyelhetố volt, tény azonban, hogy a negyvenéves kommunizmus korszaka jelentôs rombolást okozott ezen a területen is. Közép-Európában tehát a jelen és a jövố dönti el, hogy a társadalmak mennyire és milyen mértékben lesznek képesek a nyugat-európai civil politikai kultúrához hasonló állapotok kialakítására.

A modern nyugati politikatudomány a nyugati tapasztalatokra alapozva a mai civil társadalom és állampolgári politikai kultúra négy fontos elemét hangsúlyozzák:

- Az elsố az a megfontolás, hogy a civil társadalom az állammal szemben órzi az állampolgárok függetlenségét, védi szabadságukat, vagyonukat, jogaikat. Ez tehát az elválasztás, az államtól való leválás hagyományos liberális koncepciója, amely Locke gondolataiig nyúl vissza.

- A második elem szerint a civil szervezetek hozzájárulnak a társadalmi konfliktusok orvoslásához, az elitek rekrutációját segítik elô, és tehermentesítik az államot azzal, hogy fontos teljesítményeket vesznek le a válláról (lásd szolidaritásközösségek, szociális hálók, nyilvános szolgálatok átvállalása stb.). Ez a pluralizmuselméletre épüló gondolat, szemben a liberalizmuskoncepcióval, a társadalom és az állam kapcsolatát hangsúlyozza. 
- A harmadik elem kiemeli, hogy a civil társadalom múködó szervezetei a demokrácia iskolái. E Tocqueville-tól származó és mások által is átvett gondolat szerint a civil társadalom normatív, részvételi és személyes hozzájárulást ad a demokrácia megerôsödéséhez, és olyan állampolgári erényeket fejleszt ki, mint a tolerancia, egymás elismerése, kompromisszumkészség, bizalom, ószinteség és megbízhatóság (mely tulajdonságok nélkül a demokráciák aligha múködóképesek) (Tocqueville, 1993).

- Végül a negyedik elem azt hangsúlyozza, hogy a civil társadalom kiszélesíti a társadalmi érdekek artikulációját és aggregációját egy úgynevezett politika elôtti (vorpolitisch) térben, mi által a nehezen megszervezhetô és hátrányos helyzetú csoportok lehetôséghez jutnak önmaguk kifejezésére a nyilvánosság előtt. Ennek révén a rejtett társadalmi konfliktusok tematizálódnak (agenda-setting) és kezelhetôvé válnak. Ebben a megközelítésben demokrácia és civil társadalom gyakorlatilag szorosan egymáshoz kapcsolódik.

Mindezekhez hozzátenném, hogy a civil társadalom és politikai kultúra megléte vagy nem megléte nem más, mint magának a demokráciának a léte vagy nemléte, hiszen itt fogalmi azonosságról van szó. A demokrácia mint népuralom hogyan képzelhetô el másként, mint hogy a nép megszervezett, képviseli érdekeit, és részt vesz a róla szóló döntésekben? Ha ugyanis ez nincs így, akkor pusztán politikai elituralom, avagy politikai elitdemokrácia (formális, választási demokrácia) létezik, az pedig egy másfajta értelmezést igényel. Linz és Stepan ezt úgy fogalmazza meg, hogy állam nélkül nem létezik állampolgárság, állampolgárság nélkül pedig nincs demokrácia (Linz-Stepan, 1996).

Nézzük ezek után, mit tapasztalunk több mint húsz ével a rendszerváltások után Közép- és Kelet-Európában? Mint említettük, a több évtizedig tartó kommunizmus gyakorlatilag megszüntette a civil társadalmakat és kultúrát, már ahol egyáltalán volt, illetve bontakozott - azaz Közép-Európában. Kelet-Európában, a Kelet-Balkánon s fớként Közép-Ázsiában pusztán rögzültek és fennmaradtak a civil társadalom és kultúra nélküli, alattvalói állapotok, s ennek következményei jól látszanak a két alrégió közötti különbségekben. Wolfgang Merkel német politológus írja le, hogy a civil társadalom létrejötte a legnehezebb és a leghosszabb időt igénybe vevô feladat, és az elsô 20 év pontosan mutatja, hogy a térségben a hiányzó állampolgári kultúra és civil társadalmi vitalitás különlegesen erôs problémát jelent (Merkel, 2010). Ezt a tényt bizonyítja, hogy a pártok és a politikai szervezetek kevés bizalmat élveznek az emberek elôtt - a Nyugattal szemben -, s általában a jogállamba vetett hit is szignifikánsabb kisebb, mint Nyugat-Európában. Ez pedig valós probléma, hiszen a jogállamba vetett bizalom nyilvánvalóan központi kérdése a demokratikus rendszer legitimitásának.

Fontos azonban hangsúlyozni, hogy világos különbség mutatkozik Közép-Európa, illetve a kelet-európai alrégiók között. Amíg Közép-Európában Nyugat-Európához vagy az Egyesült Államokhoz képest némileg alulfejlett, de nem a demokráciával szemben álló civil társadalmak léteznek, addig, ahogy Kelet felé haladunk, utóbbi területeken már arról van szó, hogy ott soha nem létezett a civil társadalom kezdeménye sem, de hiányzik a demokrácia elvi támogatása is. Kelet-Európában - s még inkább a Kaukázuson és Közép-Ázsiában - nem alulfejlettségrôl, hanem egyszerúen nem civil 
Fricz Tamás: Civilitika - A civil társadalom kialakulása Nyugat-és Közép-Európában...

és nem polgári, tágabban nem demokratikus mentalitásról beszélhetünk. Másképpen fogalmazva, utóbbi alrégióban alattvalói kultúra van - avagy „köztes” kultúra, hibrid rendszer -, amelynek az autoriter rendszerek sokszor jobban megfelelnek, mint a demokráciák. Közép-Európában ezzel szemben alulfejlett, de a demokrácia felé irányuló civil társadalmak léteznek, ami a Nyugat felé mutat, a demokráciát tolerálja és elfogadja még akkor is, ha abban nem múködik minden jól, sôt. Az persze elképzelhetô, hogy a közép-európai demokráciák soha nem fognak hasonlítani a civil kultúra szempontjából sem mondjuk Svédországra, Németországra, Angliára vagy Hollandiára, de mégis a demokratikus irányultság keretein belül értelmezhetôk ezek az országok.

S mindehhez hozzátehetjük, hogy az európai uniós tagság, illetve a tagsági aspiráció a közép-európai, illetve az EU-ba igyekvô balkáni országok számára erôteljes elkötelezôdést jelent a demokratikus jogállamiság értékei iránt, beleértve ebbe természetesen egy hatékony és múködô civil társadalom kiépítését is. Elmondható tehát, hogy egy polgári etikai kódex érvényessége legalább annyira vonatkozik a nyugat-európai, mint a közép-európai és EU-orientált országok civil társadalmaira és állampolgáraira.

\section{A Givil társadalom Magyarországon}

Magyarországon - akárcsak Lengyelországban vagy Csehországban - már a 19. századtól kezdve megkezdődött a civil társadalom kiépülése. A dualizmus idôszaka e szempontból egyfajta „aranykor” volt, ezekben az évtizedekben virágzott ki a kulturális élet, gombamódra szaporodtak az egyletek és egyesületek, sportkörök, színes sajtóvilág bontakozott ki, élénk múvészeti és tudományos élet zajlott, egyszóval megfigyelhetô volt a civil társadalom „eredeti tôkefelhalmozása”, de leginkább intézményesedése. Mindez folytatódott a trianoni tragédia után is, 93 ezer négyzetkilométerre beszorítva, a háborús fenyegetés árnyékában, s még tartott a háború utáni elsô években, a kommunista hatalomátvételig.

Tény ugyanakkor, hogy az 1948-1949-tól 1989-1990-ig tartó kommunista, illetve szocialista diktatúra a civil társadalmat alapjaiban megtörte, szétporlasztotta; mindez megmutatkozott intézményi és mentális szempontból is. Intézményi oldalról ez azt jelentette, hogy a civil társadalom intézményeit megszüntették, felszámolták (a szerzetes- és apácarendektôl kezdve a polgári egyesületeken át a politizáló mozgalmakig és tovább), de még ennél is súlyosabb volt, hogy az emberekból kiirtották az önálló, szuverén, citoyengondolkodás gyökereit is. Ez a modern kori diktatúra - különösen annak elsố szakasza, a Rákosi-rendszer - lényegében véve megszüntette az állam és a társadalom különválasztását, s az állam újra rátelepedett a civil szférára, bekebelezte azt, nem engedte, hogy saját törvényei szerint múködjön.

Tény, hogy az 1956-os forradalom leverése utáni Kádár-korszak valamelyest engedett a diktatúra szorításán, ám ez elsôsorban abban nyilvánult meg, hogy az emberek számára némi magánéleti szabadságot engedélyezett. Továbbra sem lehetett senki állampolgár, szabad és független civil, fóleg nem honpolgár, viszont megengedték neki, hogy fogyasztópolgárként némi örömök érjék. A Kádár-korszak talán legnagyobb búne éppen az, hogy a civil lét halvány, hamis látszatát teremtette meg, ám ez a nyú- 
lós-nyálkás „langymeleg” tömegeket fogott meg és tartott az elégedettség állapotában. Mindez azonban azért nagy hátrány a mai demokrácia és civiltársadalom-építés szempontjából, mert az emberekben nem alakult ki a diktatúrával szembeni olyan ellenérzés, sôt ha tetszik, utálat, amely termékeny, cselekvô energiákba tudott volna átfordulni a rendszerváltás hajnalán, s lehetôvé tette volna, hogy bottom-up, azaz alulról jövố mozgalmak induljanak el a demokrácia megteremtése érdekében, s e folyamat során a civil társadalom alapjai megteremtôdhettek volna.

Sajnos nem így történt, a fogyasztópolgárrá leminôsített tömegek - amelyek atomizált masszává váltak - képtelenek voltak civil erôket belevinni a rendszerváltásba és demokratizációba, ami ettôl az elsố idôszakban jelentôs mértékben elitdemokráciává vált - jól múködố civil társadalom nélkül. (Megjegyzendô itt, hogy a legtöbb közép-európai és EU-tag demokráciában a civil társadalom kialakulatlansága szintén megfigyelhetố volt, természetesen országonként különbözố mértékben.)

Mindez annak ellenére így történt, hogy a Kádár-rendszer válságba fordulása idején, a nyolcvanas évek második felében gyakorlatilag ismét gombamódra szaporodtak a civil, közéleti és nemcsak közéleti jellegú szervezôdések, új szakszervezetek Magyarországon. Ugyanakkor 1988-1989-től kezdve fordulat állt be, ekkor jelentek meg az új, ellenzéki pártok, s az e pártok által irányított ellenzéki elitcsoportok koncepciója vált meghatározóvá a magyar rendszerváltás és demokratizáció karakterét illetôen. Az ellenzéki politikai elit tagjai kifejezetten és határozottan a pártokat és az államot helyezték elôtérbe az átmenet során a civil mozgalmakkal szemben; nem a civilekkel fogtak össze, hanem nagy elôszeretettel ültek le a pártállami elit vezetôivel a kialakítandó jogállam kereteinek meghatározásáról s arról, hogy abban a régi és az új elitnek milyen szerepek juthatnak. E folyamat következtében a kezdetben civil mozgalmak vezetôi pártokba léptek be, gyakran e szervezetek felszámolódtak, s így a versengó pártelitek váltak meghatározóvá, míg a társadalmi részvétel, az állampolgárok integrálása, a civil szféra ügyei jelentôs mértékben háttérbe szorultak.

A meglepően gyors „elitesedésnek” kettôs oka van. Az egyik, hogy a Kádár-korszakban a társadalom atomizálódott, az emberek fogyasztópolgárokká váltak, s távol állt tôlük az állampolgári-citoyen magatartás. Ám ez mégsem elegendô magyarázat, hiszen a rendszerváltás hajnalán mégis számos civil szervezet és mozgalom lépett a nyilvánosság elé. Éppen itt jön be a másik ok, ami az ellenzéki elit magatartásában rejlik: ez az elit dönthetett úgy is, hogy a civil szféra, az állampolgárok, ha tetszik, a tömegek felé fordul, s úgy is, hogy az állam, az akkor még pártállam elitjével kezd tárgyalásokba. Nos, az ellenzéki elit a második megoldást választotta: a pártállami elit felé fordult, ôt tekintette elsôdleges partnerének. Világossá vált, hogy - különösen a liberális ellenzéki elit - a társadalmat, az embereket amatôrnek tartotta a „magasröptú” dolgok befogadásához, szemben a saját maga professzionalizmusával.

Mindennek következtében Magyarországon a békés, tárgyalásos, alkudozós átmenet olyan ,jól” sikerült, hogy annak következtében a demokratikus jogállam civil társadalmi alapok nélkül jött létre. Létrejött a demokratikus állam, demokratikus állampolgárok nélkül. Paradox módon a rendszerváltó politikai elit is hozzájárult ahhoz, hogy a magyar társadalom és a polgárok megmaradjanak kádári magánpolgárnak (s 
Fricz Tamás: Civilitika - A civil társadalom kialakulása Nyugat-és Közép-Európában...

már nem is fogyasztópolgárnak, mert a tartós gazdasági válság következtében elvesztették állásukat, illetve nem növekedtek, inkább romlottak a jövedelmi viszonyaik). Civil társadalom helyett továbbra is csak magántársadalom létezett, atomizált polgárokkal, akiknek hiányoztak a mozgalmaik, szervezeteik és intézményeik ahhoz, hogy az állammal, a politikával kapcsolatba, szimbiózisba lépjenek.

Mindez pedig azért problematikus, mert a szabadságot, a demokráciát ki lehet vívni polgárosodás, civil társadalom nélkül is, felülrôl (elitegyezségek, külföldi támogatások által), de konszolidálni és stabilizálni nagyon nehéz, szinte lehetetlen. Mint már említettük, a nyugati példa éppen a fordítottja a magyarnak és a többi közép- és kelet-európai országénak, hiszen ott a polgárosodás alapozta meg a civilesedést, majd az állampolgárosodást és végül az állam demokratizációját, míg Magyarországon az államból indult ki a folyamat.

Csakhogy az állam önmagában nem tud mindent megoldani, nem is az a feladata: állampolgárságot, civil társadalmat hitelesen és tartósan csak alulról, polgári építkezéssel lehet megvalósítani, hosszú és nehéz folyamatban. A rendszerváltás elsô tizenöt éve be is bizonyította, hogy „állami” civil társadalom nem létezik - vagy legalábbis ingatag, és könnyen összeomlik. Ráadásul az esetleges civil kísérleteket tovább korlátozta az új - és a továbbélô kádári - elit azon gyanakvása, amellyel a civil kezdeményezéseket szemlélték, legyen az népszavazási kísérlet, népi kezdeményezés vagy hasonló. Az elit újra és újra a professzionalizmus kritikáját, sốt, plebejus, amatôr jellegú populizmust véltek felfedezni e törekvésekben, és ezért azokat igyekeztek csírájában elfojtani. Vagyis, összegzésképpen megállapítható, hogy a magyar - régi és új - elit egységes volt a civil kezdeményezések elfojtásában, s így meghatározó szerepe volt abban, hogy a civil társadalom nem bontakozhatott ki az elsố idôszakban Magyarországon.

Az elsố fordulatot a 2002-es választási kampány, pontosabban a választás elsô fordulója hozta el. Az elsố forduló után ugyanis az ellenzékben lévô, posztkommunista Magyar Szocialista Párt tett szert jelentôs elônyre, s ez valósággal sokkolta a nemzeti és konzervatív tábort, hiszen az elsô Orbán-kormány valóságos és adatokkal is igazolható eredményeket ért el a négy éve során, s ehhez képest érthetetlen volt a választási részeredmény. Ennek következményeképpen néhány nappal a második forduló előtt több százezres vagy milliós tömeg gyúlt össze a Kossuth téren, hogy hitet tegyenek az Orbán Viktor vezette kormány mellett. A választási vereség mégis bekövetkezett, ám a két forduló közötti választópolgári aktivitásra építve hirdette meg a választások után Orbán Viktor az úgynevezett „polgári körök” mozgalmát, amelynek értelmében a nemzeti érzelmú választók kis köröket alakítottak az ország minden egyes részében. E körök a 2002 és 2006 közötti idôszakban gombamódra szaporodtak, s nagy szerepük volt a civil aktivitás, az állampolgári lét alapjainak megteremtésében. Ugyanakkor az is tény, hogy e körök felülrôl, a politika felól szervezett képzôdmények voltak, de nagyon hamar saját lábra álltak, és önálló tevékenységekbe kezdtek.

Mégis, ehhez képest újabb fordulatot hozott a 2006-os év: a hírhedt „ószödi beszéd” kiszivárgása után ez év ôszén spontán, alulról jövô, nem felülrôl szervezett civil tüntetések kezdôdtek, s hosszú hónapokon át tartottak, erkölcsi alapon tiltakozva a „hazudós” miniszterelnökkel szemben, előrehozott választásokat követelve. A magyar civil társada- 
lom önszervezôdô csírái itt jelentek meg, s nem árt megjegyezni, hogy a kezdeti idôkben mi jellemezte ezeket: egyfelől a morális érzékenység, másfelól az erôs politikai tartalom. Azért fontos ez, mert a késôbbiekre nézve is meghatározó, hogy a kezdeti idôkben milyen elvek, értékek és motivációk indították el a civil társadalom kibontakozását.

A civil társadalom ébredésének harmadik, immáron még markánsabb szakasza 2009-tôl kezdôdik: ekkor lép színre a Civil Összefogás Fórum (CÖF), mely egy virágvasárnapi demonstrációra több mint kétszázezer embert vitt ki a Hốsök terére, mely helyen elótte legutoljára az 1989-es Nagy Imre-újratemetésen voltak ennyien. A CÖF is a még mindig hatalmát féltố baloldali-posztkommunista kormányzat ellen lépett fel, s tartott egymás után több demonstrációt is. Megórizte tehát a 2006-os indulás politikai és erkölcsi alapjait, s ezen a „nyomvonalon” haladt tovább, ám tevékenysége itt nem állt meg. A jobboldal 2010-es kétharmados választási gyôzelme után a CÖF kiszélesítette tevékenységét, átfogó közpolitikai és szakmai munkába kezdett, országos hálózat kiépítésébe fogott. Szakmai kerekasztalokat hozott létre, majd a kormányzat megfelelố szerveivel kapcsolatba lépett, s egyenrangú tárgyalópartnerként részt vett és vesz törvényjavaslatok kidolgozásában. A CÖF tevékenysége 2010 óta inspirálja a többi, ténylegesen vagy még csak gondolatban szervezôdô civil kezdeményezéseket, sốt a politikai paletta másik oldalának értékeit valló civil szervezôdések is egyre-másra elôbukkannak. A CÖF munkájának kulcsponti jellemzője, hogy az állammal egyenrangú, szimbiotikus viszonyba került, amely a közpolitika és szakmai kérdések kölcsönös megtárgyalásán, a nézetek és vélemények egyeztetésén alapul. Hozzá kell tenni, hogy a CÖF a közép-európai országok - fôleg Lengyelország - civil szervezeteivel is kapcsolatba lépett, sốt fellépett az Európai Unió egyes intézményeiben, így az Európai Parlamentben is. Nem mellékes az sem, hogy a Civil Összefogás Fórum mellett létrejött a CET, vagyis a Civil Együttmúködési Tanácskozás, amely a magyarországi és határon túli civil szervezetek egymáshoz kapcsolódását, közös fellépéseit hivatott organizálni. A CÖF napjainkra már országos ernyôszervezetté nôtte ki magát, az intenzív közéleti tevékenységen túl (lásd többek között a Békemenetek megszervezését) immáron közpolitikai és szakmai munkákat is végez, említést érdemel ezen belül a mezôgazdasági termelőközösség megszervezése.

Elmondható tehát, hogy az elmúlt években, de különösen 2009-tốl kezdve megfigyelhetô Magyarországon a civil társadalom nem felülrôl oktrojált, hanem spontán, alulról jövố reorganizációja, újjászervezôdése. Ez az újjászervezôdés erôs erkölcsi és politikai töltettel rendelkezik, ami közvetlen következménye annak a politika-közéleti kihívásnak, amely a kétezres évek második felében érte Magyarországot. Feltételezhetô, hogy a bontakozó magyar civil társadalom a továbbiakban is markánsan politika- és erkölcsorientált lesz, aminek a késôbbiekben nyilván oldódnia kell, s a szakkérdéseknek kell fokozatosan elôtérbe kerülnie, mert ellenkezó esetben felmerülhet a politikába, államba való átcsúszás (pártosodás) veszélye is. A civil szervezetek közül a vezetô szerepet játszó CÖF részben már el is indult a közpolitikai kérdések irányába; kérdés persze, hogy a magyar politikai küzdelmek, törésvonalak és mély megosztottságok milyen irányba viszik a civil társadalmat; a meghasadás és kettéválás, avagy a szakmai-közpolitikai alapú kiegyenlítôdés irányába. 
Fricz Tamás: Civilitika - A civil társadalom kialakulása Nyugat-és Közép-Európában...

\section{NÉHÁNy ALAPTÉTEL a GIVIL TÁRSADALOMRÓL}

A fent kifejtettek alapján, a tanulmány befejezéseképpen néhány fogalmi és elméleti alaptételt fejtenék ki a mindenkori, demokratikus civil társadalom múködésével kapcsolatban.

1.§. A civil társadalom a közélet-orientált, aktív állampolgárok és azok csoportjainak világa.

2.§. A civil társadalom nem létezik demokratikus állam nélkül; civil társadalom és állam viszonyát az egyenrangúság és partnerség jellemzi.

3.§. A civil társadalom jogilag és alkotmányos független az államtól; múködését szabadon, önálló céljai és döntései szerint alakítja.

4.§. A civil társadalom az állammal szemben ôrzi az állampolgárok függetlenségét, védi szabadságukat, vagyonukat, jogaikat.

5.§. A civil társadalom a demokrácia alapja; az állam hatalma a civil társadalomból ered, és oda is tér vissza.

6.§. A civil társadalom a részvételi demokrácia iskolája és terepe.

7.§. A civil társadalom és az azt képezô állampolgári csoportok elvégzik az állam ellenôrzését; számonkérik rajta a demokrácia jogi, politikai és normatív elvárásait.

8.§. A civil társadalom a társadalmi csoportok, a nemzetközösség erkölcsi követelményeit számonkérik az államon.

9.§. A civil társadalom - mint a hatalom forrása - a demokráciától, annak normáitól és erkölcseitôl eltávolodott, illetve a civil társadalmat megszüntetni szándékozó állammal szemben felléphet, és kötelessége is fellépni.

10.§. A civil társadalom az a közvetítô közeg, amelyen keresztül az egyén képes azonosulni a közösséggel, a társadalommal és a nemzettel, s rajta keresztül eljut az államig. E folyamat során válik az egyén önzố individuumból felelôs állampolgárrá (honpolgárrá, citoyenné).

11.§. A civil társadalom az állammal együttmúködve törekszik a közjó megvalósulására.

12.§. A civil társadalom nem a hatalomra tör, hanem a társadalmi és szociális konfliktusok kezelésére és feloldására, egyes, az állam számára megoldhatatlan feladatok átvállalására, valamint a közélet demokratikus normák és erkölcsök szerinti befolyásolására.

13.§. A civil társadalom szakmai szervezetein keresztül felszólal, véleményt mond, és egyenrangú egyeztetéseket folytat az állammal, amennyiben az állam a civil társadalom múködését, tevékenységét, jogi és intézményi kereteit érintô törvénykezésbe, jogszabály-módosításba, rendeletalkotásba stb. kezd. Elvárja és kiköveteli, hogy nélküle ne döntsön az állam a civil életet illetô ügyekben.

14.§. A civil társadalom szervezetei államhatárokon átívelő, nemzetközi civil kapcsolatokat hoznak létre, beleértve ebbe többek között az Európai Unió intézményeit és fórumait is.

15.§. A civil társadalom európai uniós szinten is törekszik az „európai állam” kontrolljára, a demokratikus normák nemzetközi szintû számonkérésére. 
Polgári Szemle $\cdot$ 15. évfolyam 1-3. szám

\section{FELHASZNÁLT IRODALOM}

Almond, Gabriel A. - Verba, Sidney (1963): The Civic Culture. Political Attitudes and Democracy in Five Nations. Princeton University Press, Princeton.

Habermas, Jürgen (1993): A társadalmi nyilvánosság szerkezetváltozása. Gondolat Könyvkiadó - Századvég Kiadó, Budapest.

Hegel, Georg W. F. (1971): A jogfilozófia alapvonalai. Akadémiai Kiadó, Budapest.

Linz, Juan J. - Stepan, Alfred (1996): Problems of Democratic Transition and Consolidation: Southern Europe, South America and Post-Communist Europe. Johns Hopkins University Press, Baltimore.

Merkel, Wolfgang (2010): Systemtransformation. VS Verlag, Wiesbaden.

Tocqueville, Alexis de (1993): A demokrácia Amerikában. Európa Könyvkiadó, Budapest. 